\title{
SUPPRESSION OF NATIONAL LIBERATION MOVEMENTS IN FERGANA REGION BY TURKESTAN MILITARY DISTRCT IN THE SECOND HALF OF XIX CENTURY
}

\author{
Ikhtiyor Bokhodirov \\ Researcher History Of Uzbekistan, National University Of Uzbekistan, Tashkent, Uzbekistan.
}

\section{ABSTRACT}

Fergana region had a very high position in the colonial system of the Russian empire in Turkestan. The most population in Turkestan lived in Fergana and the empire got a lot of profit from this region. But the national liberation movement in Fergana region had always been a big problem for the Turkestan colonial administration. The imperial government used the troops of the Turkestan Military District to keep public order and supression the uprisings in the region.

KEYWORDS: - Military district, uprising, rebels, troops, rifle, battalion, company, cossacks, military court, garrison, soldiers.

\section{INTRODUCTION}

During the 19th century the Russian empire waged large-scale wars of conquest in Turkestan. Russia made a militarized colonial system in the occupied territories. The military district was the basic of the system colonial rule in Turkestan. The military district was formed to need a regular army to completely occupy the country and keep the the Bukhara emirate, Khiva khanate under its control. The military district supported the Russian colonial system in Turkestan for 50 years.

The most troops of the Turkestan military district were located in Fergana region (except for the troops in Tashkent). Because Fergana region was the center of the rebellions in
Turkestan all the time.

\section{Discussion}

In 1875-1876, as a result of military operation by the Turkestan Military District (TMD), the Kokand khanate was occupied by the Russian Empire. On 19 February 1876 the independent Kokand khanate was abolished and Fergana region was formed inside of the Governorategeneral of Turkestan.

The uprising in 1876 in the Fergana region was participated kyrgyzs and partly uzbeks, kipchaks and tajiks. In mid-March 1876, several kyrgyz tribes led by the naymans declared war ("gazavat") on the invaders near Gulja in the Ili oasis. Khudoikul, who was related to the Ming dynasty, was proclaimed khan[1]. Mingbashi 
CURRENT RESEARCH JOURNAL OF HISTORY 2(8): 38-44, August 2021

DOI: https://doi.org/10.37547/history-crjh-02-08-09

ISSN 2767-472X

(C)2021 Master Journals

\section{Crossref do) 8 Google}

Accepted 26 $6^{\text {th }}$ August, 2021 \& Published 31 th August, 2021

Suranchi, Kuzi ponsod, Ashur Ali yasaulbashi, Azimkari (the exgovernor of Sokh) were main allies of Hudoikul.

In March, Khudoikul captured with about 1000 troops Shokhimardon and Langar in the south of Fergana region, then prepared to conquer Vadil and Chimyan. On 25 March 1876 general Kolpakovsky (the temporary commander of Turkestan Military District) sent colonel Korolkov against Khudoikul with the 3rd company of the 2 nd Turkestan rifle battalion and 100 Siberian cossacks to don't intensify again the popular uprisings in the Fergana valley. Colonel Korolkov was assisted by staff-captain Kirkin and sotnic Desyatkov. Korolkov's detachment killed most of the rebels as a result of two attacks on the near Karakia and the village of Malmut. The surviving rebels dispersed to their villages.

After the suppression of the Khudoikul uprising, kyrgyzs and uzbeks, who didn't want to submit to Russian rule, began to gather under the command of Abdullabek (he was the son of Olimbek dodkhokh and Kurbanjon dodkhokh, who were the governor of Andijan during the reign of Mallakhon) in the Alai valley. Abdullabek was the ruler of Polatkhan in Kokand for some time[2]. The governor of Fergana region, general Skobelev sent Tursunkul, Bekjan and Sarimsokhodja, who had joined military district service, with 80 men against Abdullabek. But they themselves were captured and executed by Abdullabek's troops.

After the small victors Abdullabek, Umarbek, Suleimon udaychi, Tanikul ponsod and Valikhon to'ra began to gather troops in the Yangiaryk gorge, 25 versts from Gulja, where the Russian military units were stationed. There were about 1500 of them. This movement of the rebels blocked the trade route from Turkestan through Kuldja to Kashgar.

On 23 April 1876 general Skobelev came to Kudlja to personally fight against Abdullabek. On
24 April Skobelev began an attack on the rebels with podporuchic Sinelnikov's company of 120 people, Borzhov's team of 30 sappers, 113 rifle cavalery of baron Shkatelberg, sotnic Yanushev's 23 people missile-platoon, 140 Orenburg Cossacks of cornet Kudashev[3]. If the rebels are defeated, they will not be able to retreat to Alai Skobelev mobilized major Mikhail Ionov (the head of Osh uyezd near Gulja, 1876-1883) with half-company rifle cavalery and a missileplatoon. Skobelev's soldiers won the battle of Yangiariyk gorge. The soldiers of the military district chased the defeated Abdullabek to the Alai valley.

Three soldiers from Skobelev's detachment were killed in the battle of Yangiariyk. Baron Shtakelberg, poruchic Borisov and 12 soldiers were wounded. The losses of members of the national liberation movement exceeded 150 people[4]. After this victory, several Kyrgyz tribes expressed their obedience to Russia. But it wasn't the final defeat of the rebels. Staff-captain Bogolyubov, who took part in the battle of Yangiariyk, said this about the situation: "After these events the mountaineers were completely subdued shouldn't be belived. There are still capable leaders among them and I can't guarantee anything until they experience our military power for themselves" [5].

His thoughts were correct. In may 1876 a man named Abdulkarimbek appeared among the mountain kyrgyz. He claimed to restore the Kokand khanate. Abdullabek was also not completely defeated.

The governor of the region was very worried because the Kokand khanate had just been abolished and many people in the valley wanted the khanate to be restored. Skobelev wrote a latter with the following meaning to the center about the situation: "I'm worried about the appearance of Abdulkarimbek in the mountains and pay a lot of attention it"[6]. Abdulkarimbek 
CURRENT RESEARCH JOURNAL OF HISTORY 2(8): 38-44, August 2021

DOI: https://doi.org/10.37547/history-crjh-02-08-09

ISSN 2767-472X

(C)2021 Master Journals

\section{Crossref do) 8 Google}

Accepted 26 $6^{\text {th }}$ August, 2021 \& Published 31 th August, 2021

wrote letters to uzbek, kyrgyz, tajik tribal leaders and declared that he was an ally of Abdullabek and Umarbek in the liberation movement against the invaders. He declared himself the new khan of Kokand, Said Muhammad Abdulkarimkhan ibn Said Muhammad Sadikhan and urged the tribal chiefs to join his side.

Mulla Abdurahman, Ermamat ponsod, Urazali Kyrgyz, Habib eshan were the closest people of Abdulkarimbek. Abdulkarimbek fought around Chimyan and Sokh for some time. Than he joined forces with Abdullabek.

In adittion Khudoikul reappeared near Uzgen in the Andijan uyezd in the second half of May. At the and of may the district troops under the command of sotnic Mirzinsev (100 Siberian cossacks), staff-captain Mashlikin (a platoon of the 3rd company of the 2nd Turkestan battalion) and starshina Smirnov defeated Khudoikul's military group.

After the battle of Yangiariyk Abdullabek moved around Mardansay oasis, Tokmak territory and Adgrin river along the Uzgen-Kashgar road and began to gather troops again. In the second half of June 1876 Abdullabek crushed a small punivite squad of captain Spolatboga directed against him in the Nav Jaylak near Uzgen.

The governor of Fergana region General Skobelev sent a message to the commander-inchief of TMD, adjutant-general Kaufman, said that as a result of the battle 80 people died and that it was a mistake to disregard the enemy in the fight against the rebels[7]. Skobelev feared that Abdullabek would occupy Sokh and enter the valley and that popular uprising in Fergana would escalate as a result. He sent colonel Krijanovsky to Uchkurgan with 250 soldiers to defend the Sokh and its environs. 2 infantry company and 350 cossacks in Vadil were also handed over to Krijanovsky. The russian garrison in Chimyan was located in Vadil[8].
After strengthening the roads to the Fergana valley, general Skobelev sent two military groups against Abdullabek, who was stood at the confluence of the Shot and Ak Bura rivers in the Alai valley. The first group consisted of a sanitary team of 35 people, a mixed missile platoon and ryrgyz Shabdan Dzantayev's men. The second group consisted of the 3rd and 4th company of Turksetan rifle battalion[9]. On 18 July Abdullabek, Kurbonjon dodkhokh, Umarbek and Suleimon udaichi left the territory of the Shot and Al Bura rivers without a fight as a result of an attack by soldiers of The Turkestan military district. They also took away 2000 warriors who were a main part of their army.

Skobelev sent a letter to Abdullabek through Abdurakhman Dzhantaev demanding him to surrender on 21 July. Abdullabek proved that the clonialists were not as friendly to the local people as they always said. As a condition of his surrender, Abdullabek demanded that the leadership of the Osh uyezd be handed over to Shabdan Dzhantaev and that he submit to Russia through Shabdan Jantaev. Although Shabdan Dzhantayev faithfully served the TMD, Skoblev didn't accept the condition because he was a representative of the local polulation.

After the filure of the negotiations, general Skobelev sent against the rebels fligeladjutant Wittgenstein with half a company of rifle cavalry, a hundread cossacks, two missile-launchers and the people of Shabdan Dzhantaev. But fligeladjutant Wittgenstein couldn't to catch up with the rebels retreating towards the Kizil Arvat.

General Skobelev sent the following telegram commander-in-chief of military district after the rebels retreated and several tribal leaders surrendered such as mangut, adygan and ichkilik: "In my opinion our possessing of the Great Alay will ensure peace in Fergana for the future"[10]. But the rebels continued to fight for 
CURRENT RESEARCH JOURNAL OF HISTORY 2(8): 38-44, August 2021

DOI: https://doi.org/10.37547/history-crjh-02-08-09

ISSN 2767-472X

(C)2021 Master Journals

\section{Crossref do) 8 Google}

Accepted 26 $6^{\text {th }}$ August, 2021 \& Published 31 th August, 2021

several more month.

1876 the military units of the district attacked the shapurchi tribe, located 30 wersts away from Zardolu on 7 September 1876. This tribe was continuing its resistance movement. The village of shapurchi was hardly occupied (about 800 men from the shapurchi tribe took part in the battle) and completely burnt down. In the battle, fligeladjutant Wittgenstein, captain Serpitsky, praporshic Gratevsky had a concussion. 8 people from the lower ranks were seriously injured and 27 were slightly injured. 18 men from Shabdan Dzhantaev's people were wounded.

The war in the mountains south of Fergana region was very hard for the Turkestan military district. Even the commander-in-chief of the district, general Kaufman, was admited it: "The difficulty of the war in the Fergana region was no less honorable than the conuest of the Kokand khanate"[11]. General Skobelev understood that it wouldn't be possible to establish a lasting peace by force of military in the Alai territory. He personally met Abdullabek and Kurbanjan dadkhakh and made a peace treaty based on their demands. Kurbanjan dadkhakh and her sons were given the right to personal inviolability and the permission to return to their homes. After that the uprising edned in 1876.

Preparation for nationwide uprising against the colonialists began in the Fergana region in 1885. On 16 avgust 1885 at a meeting at the house of Mullah Nazirmirza in Asaka, more than 20 influential people from different parts of the valley decided to revolt to liberate the country from the invaders and restore the national statehood[12]. Darveshkhan Eshan Tura (1840/1845-1889) from Kurghantepa volost of Andijan uyezd was elected as the leader of the upsinig. People from Asaka, Kurghontepa, Shakhrikhan, Altynkul, Jalalabad volosts in Fergana region and Novkat, Tutlik villages in Osh uyezd began to gather around Darveshkhan. At first the rebels cut the communication lines connecting Margilan with Andijan and Kokand.

There was a strong sympathy for the rebels among the local population and aven local officials. The governor of Fergana region Niloai Aexandrovich Ivanov (1883-1887) commented on it: "We can't capture Darveshkhan because the population and the local administration are not helping. Local officials are busy spreading various excuses to hide their inaction"[13].

General Rosenbach (1885-1889), the commander of the Turkestan military district (TMD), was also worrried about the Darveshkhan's rebellion. He wrote it in a latter to Russian minister of war Vannovsky (1881-1898) about uprising in Fergana: "The rebels urged the population to join the rebels without stealing or looting and it proved that the revolt was against Russian dominance"[14]. The suppression of the rebellion and the capture of Darveshkhan was entrusted to the head of the Andijan uyezd, Alexander Ilin Bryanov (1885-1887). Additional troops were sent to help Bryanov led by lt.colonel Alexander Ivanovich Deibner (18841892), the head of Osh uyezd, and his assistant captain Glishanovsky. On 17 August Bryanov suddenly attacked the rebels and smashed them.

The survived rebels fled to the volosts of Fergana region for avoid arresting. The defeated Darveshkhan fled to the Samarkand region. Then he left for Afganistan and died in 1889.

A popular uprising under the leadership Muhammad Ali eshan (1846-1898) began against the colonialists in the village Mingtepa in the Margilan uyezd in May 1898. Muhammad Ali eshan attacked the city of Andijan. The insurgent's plans to attack Margilan and Osh didn't come true because the chiefs of Margilan and Osh uyezd, colonel Bryanov and lt.colonel Zaytsev, had been warned in advance by traitors.

On 17 May the rebels stormed the barrack of the 
CURRENT RESEARCH JOURNAL OF HISTORY 2(8): 38-44, August 2021

DOI: https://doi.org/10.37547/history-crjh-02-08-09

ISSN 2767-472X

(C)2021 Master Journals

\section{Crossref do) 8 Google}

Accepted 26 $6^{\text {th }}$ August, 2021 \& Published 31 th August, 2021

4th and 5th company of the 20th Turkestan line battalion in Andijan. The 4th company consisted of 139 men, the 5 th company 136 men. There were 52 men on the 4th company on the day of the attack. 87 people weren't on the company for several reasons. 9 men got sick, 9 men were in the civil service, 27 men - at shooting practice, 26 men - at guarding and 16 men were busy with other work. 111 men from the 5th company were in the barracks. 16 men were sick and 13 men were busy in personal and public affairs[15].

The attack of the rebels on the barrack was unsuccessful. According to the lt.colonel Mikhailov (the head of the Andijan garrison) the number of rebels were from 1500 to 2000. At first the rebels attacked the soldiers of the 2nd platoon of the 4th company. Dnevalny Tyutin (the platoon's guard) was killed at the beginning of the attack. After the 4th company duty soldier Zhernov, who tried to wake up the barracks, and dnevalny Maslennikov were also killed. Unterofficer Stepanov in the 3rd platoons woke up the survivors and ordered everyone to take up arms and retreat to the 5th company[16].

The temporary commander of the 5th company podporuchic Karseladze went to the help the 4th company with the soldiers of the 5th company after receiving information about the attack on the barracks. The rebels (they were armed with swords, daggers, clubs, axes and plundered garrison rifles) began to retreat after the garrison soldiers counterattacked. Garrison's chief lt.colonel Mikhailov said the main part of the rebels survived because the bullets ran out. As a result of the attack 23 soldiers of the Andijan garrison were killed and 30 rifles were stolen from the barrack[17]. Lt.colonel Mikhailov decided not to pursue the rebels. He immediately returned 5 officers and 22 soldiers of the 4th company to the garrison, who went to the shooting practice under the command of podporuchic Rosalion-Soshalsky[18].
There was excessive panic in the new part of Andijan at the time of the uprising. People, officals even the head of Andijan uyezd, colonel Konshevky, hid in their homes. Konshevsky knew that the rebels had left the city when the Khalbatir Ruzadorbiy ugli (the head of the old city) come to his house.

On 18 may the temporary general-governor of Turkestan leutenant-general Nikolai Ivanovich Korolkov ordered about the cancellecation of summer training in military district, the dispatching of punitive detachments to Fergana region, the giving of rifles to Europeans and reliable local officials.

Just in case 1 company, 25 snipers from Osh and 1 company, 20 snipers of 20th Turketan lineregular battalion from New Margilan were brought to Andijan on 18 May. 1 company and 50 snipers were sent to pursue Dukchi eshan from Namangan[19].

The minister of war Alekxander Nikolaevich Kuropatkin (1898-1904) appointed Sergei Mikhailovich Dukhovsky (1898-1901) as the new commander-in-chief of the Turkestan Military District. Kuropatkin sent him the following telegram (№ 25724) for suppressing the uprising and ending the riots in the Fergana region. The following was done by Kuropatkin's order:

- The head of the punitive detachment, general Korolkov went to Fergana and interrogated the people who attacked Russian troops.

- The governor of the Fergana region Alexander Nikolaevich Povalo-Shveykovsky (1893-1898) and the head of the Andijan uyezd colonel Konshevsky (1895-1898) were dismissed.

- The commander of the 1st Turkestan regular brigade, general Ionov, was sent to Fergana and appointed commander of the region's troops.

- 200 cossacks of the 2nd Ural Cossack regiment under the command of colonel Jigalin were sent 
CURRENT RESEARCH JOURNAL OF HISTORY 2(8): 38-44, August 2021

DOI: https://doi.org/10.37547/history-crjh-02-08-09

ISSN 2767-472X

(C)2021 Master Journals

\section{Crossref do) 8 Google}

Accepted 26 $6^{\text {th }}$ August, 2021 \& Published 31 ${ }^{\text {th }}$ August, 2021

to Fergana from Samarkand.

- The troops of the Pamir border post were strengthened.

- The Commander of the 2nd Transcaspian rifle brigade Andrei Petrovich Tchaikovsky (18981901) was appointed governor of the Fergana region. Colonel Chernyaevsky and Krilov was appointed his assistants[20].

Korolkov formed a special military filed court. The court consisted of lt.colonel Deval (the head of the general-governor's administration), lt.colonel Romanovich (the editor of the Turkestanskie vedemosty (')'), colonel Nekrasov (the prosecutor of the military district court) and colonel Nekrasov (the military investigator on important cases). Korolkov arrived in Andijan on 23 may. The punitive expedition was organized on the basis of the 1 st rifle battalion, the 5 th Orenburg cossack regiment and the 5th "hunting detachment" by Korolkov's order[21].

The traitors Kadrykul mingbashi and Mateokub kurbashi seized Dukchi Eshan near the Charvak village and handed him over to staff-kaptain Ogabekov. Punishment squads arrested 777 people suspected of uprising. General Mikhail Afrikanovich Terentev presided over the investigation. 380 people were sentenced to death after the investigation. But Dukhovsky changed the death sentences of 362 people to other punishments in order not to intensify popular protest: 147 people to 20 years, 47 to 7 years, 41 to 15 years, 4 to 4 years, a man to 13 years, a man to 8 years and 3 to life imprisonment were arrested. 15 people were deported to Siberia and 3 children were sentenced to educational prison[22].

After the uprising colonialists forced the people to bow to Russian officials and the military in order to humiliate the local people. The property of the rebels and many people unrelated to the uprising was also confisticated. The colonial administration destroyed the willages of Mingtepa, Tajik, Kashgar, Kutchi and Kokand with artillery and relocated the population to the Kakir steppe. Russians were immigrated to the empty area from Saratov and Samara provinces.

The temporary military court with the participation of lt.colonel Antufev (from Turkestan artillery brigade), colonel Naumov (from 6th Orenburg cossack regiment), lt.colonel Rukin (from 4th Turkestan line battalion), lt.colonel Savitsky (from 7th Turkestan line battalion) and general Dolinsky (yhe military prosecutor of TMD) convicted to death Muhammad Ali eshan on 11 June[23]. Muhammad Ali eshan, Goibnazar Ortikhoja ugli, Subkhonkul Arabbaev, Rustambek Sotiboldiev, Mirzo Khamdam Usmanbaev from the leader of the uprising were executed in front of 8000 local people (2000 of them were school's children) in Tuprakurgan of Andijan[24].

The administration of the military district gave 16095 soums to the families of soldiers killed in the uprising. Even amir Abdulahad (1885-1910) sent 1600 soums to Tashkent for this purpose[25]. The administration rewarded the military for being active during the suppression of the uprising. Staff-captain Ogabekov and podporuchic Karseladze were awarded the order of St. Vladimir (4th degree), lt.colonel Mikhailov was awarded the rank of colonel.

\section{Conclusion}

In the second half of the 19th century the national liberation movement in Fergana region proved that Turkestan had been invaded by the Russian empire. The main reasons for the uprising were the difficulty of taxes and levies, the betrayal of local officials, the transfer of arable lands to immigrations from Russia, the rising prices, the impoverishment of the population.

The national liberation movement has been 
CURRENT RESEARCH JOURNAL OF HISTORY 2(8): 38-44, August 2021

DOI: https://doi.org/10.37547/history-crjh-02-08-09

ISSN 2767-472X

(C)2021 Master Journals

\section{Crossref do) 8 Google}

Accepted 26 $6^{\text {th }}$ August, 2021 \& Published 31 th August, 2021

going in many parts of Fergana region on since 1870s. Although these uprisings took place in certain territories, its affected the whole region. Each rebellions caused the beginning protests elsewhere. After the uprisings were suppressed, its participants continued their activities in other parts of the region.

Unfortunately, the weakness in weapons was the main reason for the defeat of the rebels. The Russian empire reached this advantage through the army of the Turkestan military district in Turkestan.

\section{ReFERENCES}

1. Uz NA, I 715th stock, 1th list, 167th work, p. 197.

2. Mulla Niyoz Muhammad Khoqandiy. Ibratul xavoqin (Tarixi Shoxruxiy). - T.: Turon zamin ziyo. 2014. - p. 336.

3. Bobobekov H.N. Pulatkhan's rebellion. Tashkent., 1996. - p. 45-47.

4. Bobobekov H.N. Pulatkhan's rebellion. Tashkent., 1996. - p. 48.

5. Uz NA, 1396th stock, 2nd list, 96th work, 37 th page

6. Uz NA, 1396th stock, 2nd list, 97th work, p. 34.

7. Uz NA, I 715th stock, 1th list, 68th work, p. 153-154.

8. Bobobekov H.N. Pulatkhan's rebellion. Tashkent., 1996. - p. 50.

9. Bobobekov H.N. Pulatkhan's rebellion. Tashkent., 1996. - p. 51.

10. Uz NA, I 715th stock, 1th list, 68th work, p. 246

11. Uz NA, I 715th stock, 1th list, 69th work, p. 200.
12. Shamsutdinov R.T., Ishoqov A.A. The excerpts from the history of Andijan. Tashkent: Sharq. 2013. - p. 177.

13. Ziyoyev $H$. The fight against Russian aggression and dominantion in Turkestan. - T.: Sharq. 1998. - p. 386.

14. Shamsutdinov R.T., Ishoqov A.A. The excerpts from the history of Andijan. - T.: Sharq. 2013. - p. 178-179.

15. Egamnazarov A. Dukchi eshan who you know. - Tashkent: Sharq. 1994. - p. 45

16. Uz NA, I 1th stock, 31th list, 91th work, - p. 18-19.

17. Fozilbek Otabek ug'li. The story of Dukchi eshan. - Tashkent: Cho'lpon. 1992. - p. 30.

18. Egamnazarov A. Dukchi eshan who you know. - Tashkent: Sharq. 1994. - p. 45.

19. Egamnazarov A. Dukchi eshan who you know. - Tashkent: Sharq. 1994. - p. 8, 4647.

20. Shamsutdinov R., Karimov Sh., Xoshimov S. Homeland history. 2nd book. - T.: Sharq. 2016. - p. 205-206.

21. The new history of Uzbekistan 1 th book. The period of tsarist colonization in Turkestan. -T: Sharq. 2000. - p. 367.

22. Ziyoyev H. The fighting against Russian aggression and domination in Turkestan. T.: Sharq. 1998. - p. 397.

23. Egamnazarov A. Dukchi eshan who you know. - Toshkent: Sharq. 1994. - p. 74-75.

24. Fozilbek Otabek ugli. The story of Dukchi eshan. - Toshkent: Cho'lpon. 1992. - p. 49.

25. Ziyoyev $\mathrm{H}$. The fighting against Russian aggression and domination in Turkestan. T.: Sharq. 1998. - p. 397. 